〜25分間吸入で正確な血流童を得られたことを報告した。 また新アルゴリズムにより約 6 枚の CT 画像で $\mathrm{f}$, 入イ メージの構成時間が約 2 分と短縮され実用性が高まって いるので今後の臨床に期待が持たれる。

演題277 (守部) は Auto Voice 機能のないCT 装置に CT 装置の電気回路,ソフトウェアに手を加えないで, 自 作の Auto Voice 装置を開発しその機能，回路等を発表 した。患者数の多い病院ではAuto Voice は不可欠と思 われるのでメーカの協力を得てもう少しスマートに改造 できなかったものだろうか？

質問（シーメンスメディカル，村上）演題274で1 $\mathrm{CBF}$ の変動を 7 〜 $10 \%$ と発表しているが, 何に対しての $\%$ か?

答 スムージング処理をした画像 6 枚によって得られ た $1-\mathrm{CBF}$ を100\%とした。

質問 （小児医療センター，松田）骨とロッドの骨塩 童は被写体厚の変化に対して同じように変化したか？

答いわゆるビームハードニングに注目したデー夕は とっていない.

質問（香川医大，桂川） CT で得ら扎る局所脳血流 童は絶対値と考えて良いか？

答 放射性 Xe ガス吸入によるデー夕等と比較しても $\mathrm{X}-\mathrm{CT}$ で得ら机る CBF は絶対值と考えて良いと思う。

質問（独協医大, 松村） CBF 测定には患者の固定が 重要と思うが，患者の動きを掞さえるため安静剤を使用 しても良いか?

答 $\mathrm{CBF}$ は脳の機能検查という意味から考えて, 安静 剤は使用していない。

質問（香川医大，桂川） $80 \mathrm{kV}$ でスキャンしている と $1 \mathrm{kV}$ の変動によって血流歯值が $10 \%$ 変化するようで あり，管電圧の管理が重要であると思うがその安定性は 良いか?

答 一般に管電压は安定している。しかし装置の定期 的な点検は行うのが望ましい。

まとめ

骨塩定量, $\mathrm{CBF}$ の測定ともにX線 CT の新しい応用分 野として今後の臨床応用がますます増加するものと予想 されるので，ファントム等による定電的研究による性能 評価研究の必要性を感じる.

XCT-5 品質管理（演題番号278～282）

朝比奈清敬（東芝那須工場）

X線 CT スキャナの品質管理に関する五つの演題につ いて討論した。国立がんセンター病院花井は毎回意欲的
に品質管理について報告している.今回はその 4 という ことで「最適予防点検周期の設定について」述べた。

考え方が少し難しい（数式を用いる点など）が，考察 における「点検周期を決定する上で，コスト最小の立場 でいくのか，信頼度最大の考え方でいくのかは，各病院 ごとに実情に合わせて選択すべきである」という考え方 は全くそのとおりだと言える。

九州大学医学部附属病院 馬場仁は「CT 用テストパ ターンのフィールド試験報告」において各施設間のグレ ースケールに扔ける濃度差が大きいこと，また画面中央 と画面端における濃度にも差があることを示した.テス トパターンを統一規格として各施設に供給すべきかと考 える。

福島県立医科大学放射線部 佐藤等は「スライスプロ フィールの形状と臨床画像に及ぼす影響」について述べ た.スライスプロファイルはわれわれの考えている以上 に画質に影響を与える，耳小骨などスライスプロファイ ルの改善で思いがけなく画質が向上する.MRIについて も同様のことがいえる．各メーカとも傾斜磁場に工夫を こらしてスライスプロファイルの改善に努めている.

福井医科大学付属病院 放射線部 山本等は「 $「 T$ 性 能評価項目「雑音」の算出の検討」において線質による 雑音の変動について述べた。

東芝 渋川等は「X線 CT 品質保証ソフトウェアとフ アントムの開発」において，装置性能が維持されている ことを簡便に確認できる仕組みとして，画像評価を自動 的に実施するのに適したファントムとスキャン，測定， 結果の表示を自動的に行うソフトウェアを報告した。

品質管理に関する一つの方向を示している.

今回の五つの演題についての議論をとおして，高度な 技術を駆使する医療機器の品質管理がますます重要であ ることを痛感した。

\section{X-CT-6 撮影技術（演題番号365～369）}

山下 緑（関東逓信病院放射線科）

本演題群は，撮影技術に関する内容で 5 題の発表が行 われた. CT の撮影技術は,すでにルーチン検査として撮 影法が確立された部分と, 今だ曖昧で必ずしも確立され ているとはいえない部分がある。それは近年の新しい診 断技術の登場と，高精能装置を用いた CT 検査が，精密 検査として診断の正確度を高める手段として, その応用, 適応範囲を拡大していることにあると考える，新システ 厶の装置開発が一段落した感のある今日，われわれ技師 に求められているのは, 精度の高い検查技術を確立する 